Chirurgia (2019) 114: 234-242

No. 2, March - April

Copyright@ Celsius

http://dx.doi.org/10.21614/chirurgia.114.2.234

\title{
Perioperative Anemia and Transfusion in Colorectal Cancer Patients
}

\author{
Irina Ristescu ${ }^{1,2}$, Georgiana Pintilie', Diana Filip ${ }^{1}$, Mirel Jitca', Rafaela Fecheta', Ioana Florescu', \\ Viorel Scripcariu ${ }^{1,3}$, Daniela Filipescu ${ }^{4,5}$, Ioana Grigoraș ${ }^{1,2}$ \\ ${ }^{1}$ „Grigore T. Popa” University of Medicine and Pharmacy, Iasi, Romania \\ ${ }^{2}$ Anesthesia and Intensive Care Department, Regional Institute of Oncology, Iasi, Romania \\ ${ }^{3}$ Surgery Department, Regional Institute of Oncology, lasi, Romania \\ ${ }^{4}$ "Carol Davila” University of Medicine and Pharmacy, Bucharest, Romania \\ ${ }^{5}$ "CC Iliescu" Institute for Cardio-vascular Diseases, Bucharest, Romania
}

Corresponding author:

Ristescu Irina, MD

Anesthesia and Intensive Care Department Regional Institute of Oncology, lasi, RO

E-mail: anca.ristescu@umfiasi.ro

\section{Rezumat}

Anemia perioperatorie și transfuzia la pacientii cu cancer colo-rectal

Introducere: Anemia şi transfuzia reprezintă factori de risc independenți de evoluție nefavorabilă în cancerul colorectal. Anemia severă poate creşte agresivitatea tumorală iar transfuzia poate induce imunosupresie, promovând astfel recurența cancerului. Strategiile de Gestionare a Sângelui Pacientului (GSP), specifice pentru pacienții oncologici, sunt în prezent insuficient definite şi recomandate.

Obiectiv primar: Evaluarea prevalenței anemiei şi a ratei de transfuzie perioperator la pacienții cu neoplasm colorectal. Obiectiv secundar: Analiză subgrup pacienți anemici versus non-anemici, cancer de colon versus cancer rectal.

Metodă: Am evaluat retrospectiv datele pacienților oncologici chirurgicali consecutivi admişi în intervalul Ianuarie-Iunie 2017. Am selectat pacienții cu chirurgie abdominală inferioară şi ulterior chirurgie colo-rectală. Au fost înregistrate dinamica perioperatorie a valorilor hemoglobinei (preoperator $=\mathrm{Hb} 1$, postoperator $=\mathrm{Hb} 2$, la externare $=\mathrm{Hb} 3$ ), prevalența şi severitatea anemiei, rata de transfuzie. Analiza statistică a utilizat testele t Student, Wilcoxon şi Chi-pătrat din programul SPSS 17.0.

Rezultate: Din 1284 pacienți evaluați, 546 au fost supuşi chirurgiei abdominale inferioare şi 260 chirurgiei colorectale. Vârsta medie a fost de $65.6 \pm 11.1$ ani, 57.7\% gen masculin. Dinamica perioperatorie a hemoglobinei a fost $\mathrm{Hb} 1 / \mathrm{Hb} 2 / \mathrm{Hb} 3=12 / 10.6 / 10.4 \mathrm{~g} / \mathrm{dl}$. Prevalența anemiei preoperator/ postoperator/ la externare a fost 
$52.3 / 82.3 / 82.6 \%$. Rata de transfuzie a fost $23.8 \%$ cu o distribuție pre/intra/postoperator de 2.3/11.9/10.8\%. Pacienții anemici au fost mai vârstnici $(\mathrm{p}=0.005)$, au avut o rată de transfuzie mai mare $(\mathrm{p}=0.001)$ şi o durată mai lungă de spitalizare $(\mathrm{p}=0.04)$. Cancerul de colon versus rect a fost asociat cu valori mai reduse ale $\mathrm{Hb}(\mathrm{p}=0.001)$ şi o prevalență mai mare a anemiei preoperatorii $(\mathrm{p}=0.001)$.

Concluzii: Perioperator pacienți cu cancer colorectal au o prevalență mare a anemiei, ce depăşeşte 80\% la externare şi impune transfuzia de sânge în aproximativ 25\% cazuri. Considerăm necesară implementarea urgentă a Programului GSP la această categorie de pacienți chirurgicali.

Cuvinte cheie: anemie, transfuzie, cancer colo-rectal

\section{Abstract}

Background: Both anemia and blood transfusion are now considered independent risk factors for poor outcome in colorectal cancer patients. Severe anemia can increase tumor aggressiveness and blood transfusion may induce immunosuppression and promote cancer recurrence. Specific Patient Blood Management (PBM) strategies for oncological surgical patients are insufficiently defined and recommended.

Primary objective: Evaluation of the perioperative anemia prevalence and transfusion rate in colorectal cancer patients. Secondary objectives: Sub-group analysis of anemic versus non-anemic patients and colon versus rectal cancer patients.

Methods: We retrospectively reviewed records from all consecutive surgical oncological patients admitted between January and June 2017. We selected major lower abdominal surgical patients and then colorectal surgical patients. The dynamics of perioperative hemoglobin values (preoperative $=\mathrm{Hb} 1$, postoperative $=\mathrm{Hb} 2$, at discharge $=\mathrm{Hb} 3$ ), anemia prevalence and transfusion rate were evaluated. Statistical analysis used Student t test, Wilcoxon signed-rank and Chi-square tests from SPSS 17.

Results: Of the 1284 patients screened, 546 patients were submitted to major lower abdominal surgery and 260 patients to colorectal cancer surgery. The mean age was $65.6 \pm 11.1$ years, $57.7 \%$ males. The perioperative dynamics of hemoglobin was Hb1/Hb2/Hb3 =12/10.6/10.4 g/dL. Anemia prevalence was 52.3/82.3/82.6\% preoperatively/postoperatively/at hospital discharge. Global transfusion rate was $23.8 \%$, with pre/intra/postoperative distribution of $2.3 / 11.9 / 10.8 \%$. Anemic patients were older $(\mathrm{p}=0.005)$, with a higher transfusion rate $(\mathrm{p}<0.001)$ and a longer hospital length of stay $(\mathrm{p}=0.04)$. Colon cancer patients had lower Hb values $(\mathrm{p}=0.001)$ and higher prevalence of preoperative anemia $(\mathrm{p}=0.001)$ comparing with rectal cancer patients.

Conclusions: Colorectal cancer patients have a high prevalence of perioperative anemia, exceeding $80 \%$ at hospital discharge and requiring transfusion in about $25 \%$ of cases. There is an urgent need of PBM program implementation in this selected group of surgical patients.

Key words: anemia, blood transfusion, colorectal cancer

\section{Background}

Despite tremendous, ongoing efforts in the field of prevention and early diagnosis, cancer incidence and mortality are constantly growing around the world (1). Colorectal cancer currently represents the third type of cancer in both genders and the second leading cause of cancer death in USA (2). Surgical resection of the tumor stands as the backbone of the curative treatment for these types of cancer. During the perioperative period, many surgical and 
anesthetic factors and interventions can induce immune suppression, increasing the vulnerability of the patients to cancer recurrence $(3-5)$. Among these, both anemia and blood transfusion are recognized as risk factors for poor outcome.

Anemia is a frequent and important problem in colorectal cancer patients. The etiology is multifactorial and bleeding, nutritional deficiencies, chronic inflammation, tumor infiltration of bone marrow, decreased erythropoietin synthesis and myelosuppression from cancer treatment are among the common causes. The presence of the preoperative anemia is now recognized as an independent risk factor for postoperative morbidity and mortality in surgical patients (6). In colorectal cancer patients, anemia, even mild degree, was shown to be a risk factor for postoperative complications and longer hospital stay (7). These findings generated the actual recommendations to diagnose and correct different causes of anemia in preoperative period (8).

Beside these short-term negative effects, in oncological patients anemia can also alter the long-term outcome by increasing the risk of cancer recurrence. The presence of severe anemia can aggravate intra-tumoral hypoxia, increasing HIF-1a expression and promoting target gene transcription involved in angiogenesis, proliferation and metastasis (9).

In clinical practice, the most frequently used treatment of moderate or severe anemia is red blood cell (RBC) transfusion. While being potentially life-saving in specific circumstances, transfusion can also be dangerous. Previous studies found transfusion as an independent risk factor for adverse patient outcomes, being associated with increased length of hospital stay related to sepsis and multi-organ dysfunction and increased mortality $(10,11)$. In colorectal cancer patients, perioperative administration of RBC transfusion was shown to increase all-cause mortality, cancer-related mortality, combined recurrence-metastasisdeath, postoperative infection and surgical reintervention (12). In a recent large cohort study of 4000 patients, perioperative RBC transfusion was associated with worse cancer prognosis after curative colorectal resection, independently of anemia status (13). The potential mechanism, transfusion related immunomodulation (TRIM), act primary by reducing the cellular immune response, but also increases the production of growth factors that can promote tumor proliferation and metastasis $(14,15)$.

The aim of the current study was to evaluate the perioperative prevalence of anemia and transfusion rate in surgical patients with colorectal cancer.

\section{Methods}

\section{Study design}

After approval by Institutional Research Ethics Committee of Regional Institute of Oncology, Iasi, Romania, we performed a retrospective cohort study of colorectal cancer patients admitted in Anesthesia and Intensive Care Department (Postoperative Care Unit or Intensive Care Unit) over a 6 month period from January to June 2017.

\section{Participants}

The inclusion criteria were as follows: patient age $>18$ years, preoperative confirmed or suspicious diagnosis of colorectal cancer, undergoing elective colorectal surgery. Exclusion criteria were postoperative diagnosis of benign tumors, minor surgery, local anesthesia or monitored anesthesia care.

The primary objectives were the evaluation of perioperative prevalence and severity of anemia and the transfusion rate in colorectal cancer patients. Secondary objectives were to perform a sub-group analysis of anemic versus non-anemic patients and colon versus rectum cancer patients.

\section{Recorded Parameters}

Eligible patient data were collected from the 2017 National Audit on Anemia Prevalence and Transfusion Rate proposed by the Patient Blood Management Romanian Group. This audit collected information on patient charac- 
teristics, tumor type, surgical intervention, perioperative hemoglobin level, perioperative blood loss, blood transfusion and ICU and hospital LOS of all consecutive patients undergoing surgical interventions in 6 hospitals in Romania, including our institution. Multiple sources were used to complete the database - the general hospital database, the electronic and paper medical files and the internal Blood Bank database.

For the present study, the following variables were recorded: (1) patient demographic data (age, height, weight, BMI), (2) preoperative surgical diagnosis - tumor location, (3) surgery duration (4) blood loss (intra and postoperative) (5) perioperative hemoglobin values, (6) perioperative RBC transfusion, (7) transfusion index, (6) ICU and hospital LOS.

The surgical diagnosis was classified as colon (right, transverse and left) cancer and rectal cancer.

Hemoglobin $(\mathrm{Hb})$ values were collected at 3 different time points - preoperatively ( $\mathrm{Hb} 1)$, postoperatively measured in the first 24 hours $(\mathrm{Hb} 2)$ and at hospital discharge (Hb3).

Anemia was defined according to the World Health Organization (WHO) as a value of $\mathrm{Hb}<12 \mathrm{~g} / \mathrm{dL}$ in women and $\mathrm{Hb}<13 \mathrm{~g} / \mathrm{dL}$ in men at it was classified in 3 degrees of severity as follows:

- Mild anemia

- $\mathrm{Hb}=11-11.9 \mathrm{~g} / \mathrm{dL}$ in women, $12-12.9 \mathrm{~g} / \mathrm{dL}$ in men.

- Moderate anemia

- $\mathrm{Hb}=8-10.9 \mathrm{~g} / \mathrm{dL}$ in women, $9.0-11.9 \mathrm{~g} / \mathrm{dL}$ in men

- Severe anemia

- $\mathrm{Hb}=5-7.9 \mathrm{~g} / \mathrm{dL}$ in women, $6-8.9 \mathrm{~g} / \mathrm{dL}$ in men.

\section{Statistical Analysis}

Continuous variables were analyzed using descriptive statistics. The normal distribution was checked and if data were normally distributed, central tendency was expressed as mean \pm standard deviation. Means were compared using Student's t-test. Non-normally distributed continuous variables were analyzed using Wilcoxon signed-rank test. Categorical variables are reported as frequencies and percentages and were analyzed with Fisher exact test or Chi-square test. A probability value $<0.05$ was considered statistically significant. Statistical analysis was performed using SPSS 14.0 for Windows (SPSS Inc., Chicago, IL, USA) software.

\section{Results}

\section{Perioperative anemia prevalence and transfusion rate}

In total, 1284 patients underwent elective surgery for solid tumors, 571 patients were submitted to major lower abdominal surgery and 260 patients to colorectal cancer surgery (Fig. 1). Patient baseline characteristics and the values of perioperative variables are listed in Table 1. The studied group, with a mean age of $65.6 \pm 11.1$ years and a mean BMI of $26.6 \pm 5 \mathrm{~kg} / \mathrm{m}^{2}$, included $150 \mathrm{men}$ and 110 women. The most common surgical diagnosis was rectal cancer $(52.7 \%)$ followed by right colon $(21.2 \%)$, left colon (19.2\%) and transvers colon $(6.9 \%)$ cancer.

The dynamic of the hemoglobin in the perioperative period was evaluated. From a mean value of $\mathrm{Hb} 1=12(2.1) \mathrm{g} / \mathrm{dL}$ in the preoperative

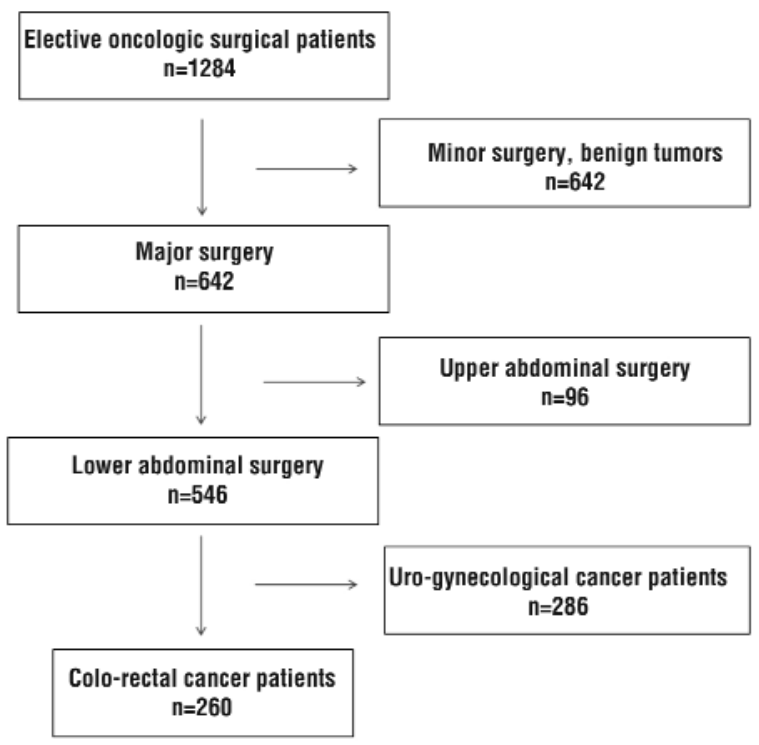

Figure 1. Study flow diagram 
Table 1. Colorectal cancer patient baseline characteristics $(n=260)$. Values are expressed as means (SD) except where indicated

\begin{tabular}{|c|c|c|}
\hline & Number & Percentage \\
\hline Age (years) & $65.6(11.1)$ & \\
\hline \multicolumn{3}{|l|}{ Gender } \\
\hline Male & 150 & 57.7 \\
\hline Females & 110 & 42.3 \\
\hline BMI $\left(\mathrm{kg} / \mathrm{m}^{2}\right)$ & $26.6(5)$ & \\
\hline \multicolumn{3}{|l|}{ Tumor location } \\
\hline Right colon & 55 & 21.2 \\
\hline Transverse colon & 18 & 6.9 \\
\hline Left colon & 50 & 19.2 \\
\hline Rectum & 137 & 52.7 \\
\hline Surgery duration (min) & $126(74.5)$ & \\
\hline \multicolumn{3}{|l|}{ Blood loss (ml) } \\
\hline Intraoperative & $200.4(202.7)$ & \\
\hline Postoperative & 119.9 (102.9) & \\
\hline \multicolumn{3}{|l|}{ Hemoglobin $(\mathrm{g} / \mathrm{dl})$} \\
\hline Hb 1 preoperative & $12(2.1)$ & \\
\hline $\mathrm{Hb} 2$ postoperative & $10.6(1.6)$ & \\
\hline $\mathrm{Hb} 3$ at discharge & $10.4(1.6)$ & \\
\hline \multicolumn{3}{|l|}{ Anemia prevalence } \\
\hline Preoperative & 136 & 52.3 \\
\hline Postoperative & 214 & 82.3 \\
\hline At discharge & 215 & 82.6 \\
\hline \multicolumn{3}{|l|}{ Transfusion Rate } \\
\hline Perioperative & 62 & 23.8 \\
\hline Preoperative & 6 & 2.3 \\
\hline Intraoperative & 31 & 11.9 \\
\hline Postoperative & 28 & 10.8 \\
\hline Transfusion index & 2.2 & \\
\hline ICU LOS (days) & $1.3(1.9)$ & \\
\hline Hospital LOS (days) & 11. (4) & \\
\hline
\end{tabular}

period, the hemoglobin decreased to $\mathrm{Hb} 2=$ 10.6 $(1.6) \mathrm{g} / \mathrm{dL}$ in the first 24 hours postoperatively. The mean surgery duration was 126 (74.5) $\mathrm{min}$, intraoperative blood loss $=200.4$ $(202.7) \mathrm{ml}$, postoperative blood loss $=119.9$ (102.9) $\mathrm{ml}$, ICU LOS 1.3(1.9) days, and hospital LOS 11 (4) days. The mean value of hemoglobin at the hospital discharge was $\mathrm{Hb} 3$ $=10.4(1.6) \mathrm{g} / \mathrm{dL}$ (Table 1).

At hospital admission, a number of 136 colorectal cancer patients were anemic, corresponding to a $52.3 \%$ prevalence of preoperative anemia. The percentage markedly increased in the postoperative period $-82.3 \%$ and at hospital discharge - 82.6\%, as shown in Table 2, Fig. 2.

The degrees of anemia severity are presented in Fig. 2. Moderate anemia was predominant in all perioperative phases. However, severe anemia prevalence increases from the preoperative $(6.5 \%)$ to the postoperative $(8.8 \%)$ period, reaching the highest level at the hospital discharge (10.3\%). Overall, the transfusion rate in colorectal cancer patients during the perioperative period was $23.8 \%$. The administration of $\mathrm{RBC}$ transfusion was the most frequent in the intraoperative (11.9\%) and postoperative $(10.8 \%)$ versus preoperative $(2.3 \%)$ period. The global transfusion index was 2.2 (Table 1).

Table 2. Characteristics non-anemic versus anemic colorectal cancer patients. Values are expressed as means (SD) except where indicated

\begin{tabular}{|c|c|c|c|c|}
\hline & $\begin{array}{c}\text { All patients } \\
n=260\end{array}$ & $\begin{array}{c}\text { Non anemic patients } \\
n=124\end{array}$ & $\begin{array}{c}\text { Anemic patients } \\
n=136\end{array}$ & $\mathrm{p}$ value \\
\hline Age (years) & $65.6(11.1)$ & $63.1(11.8)$ & $67.9(10.5)$ & 0.005 \\
\hline \multicolumn{5}{|l|}{ Gender, $\mathrm{n}(\%)$} \\
\hline Male & $150(57.7)$ & $67(54)$ & $83(61)$ & 0.254 \\
\hline $\mathrm{BMI}\left(\mathrm{kg} / \mathrm{m}^{2}\right)$ & $26.6(5)$ & $27.3(5)$ & $25.9(5)$ & 0.026 \\
\hline \multicolumn{5}{|l|}{ Tumor location, $n(\%)$} \\
\hline Right, transverse, left colon & $47.3(123)$ & $37.4(46)$ & $62.6(77)$ & $<0.001$ \\
\hline Rectum & $52.7(137)$ & $56.9(78)$ & $43.1(59)$ & \\
\hline \multicolumn{5}{|l|}{ Blood loss (ml) } \\
\hline Intraoperative & $200.4(202.7)$ & $180.9(160.1)$ & $210.7(226.3)$ & 0.111 \\
\hline Postoperative & $119.9(102.9)$ & $114.7(97.2)$ & $122.9(109)$ & 0.262 \\
\hline \multicolumn{5}{|l|}{ Hemoglobine $(g / d L)$} \\
\hline Hb 1 preoperative & $12(2.1)$ & $13.6(1)$ & $10.4(1.6)$ & $<0.001$ \\
\hline Hb 2 postoperative & $10.6(1.6)$ & $11.7(1.4)$ & $9.6(1.2)$ & \\
\hline $\mathrm{Hb} 3$ at discharge & $10.4(1.6)$ & $11.4(1.3)$ & $9.5(1.2)$ & \\
\hline RBC transfusion (\%) & $62(23.8)$ & $6(4.8)$ & $56(41.1)$ & $<0.001$ \\
\hline ICU LOS (days) & $1.3(1.9)$ & $1.1(1.2)$ & $1.5(2.4)$ & 0.092 \\
\hline Hospital LOS (days) & $11(4)$ & $10.3(3.9)$ & $11.4(4.6)$ & 0.04 \\
\hline
\end{tabular}


Figure 2. Perioperative anemia prevalence and severity in colorectal cancer patients $(n=260)$

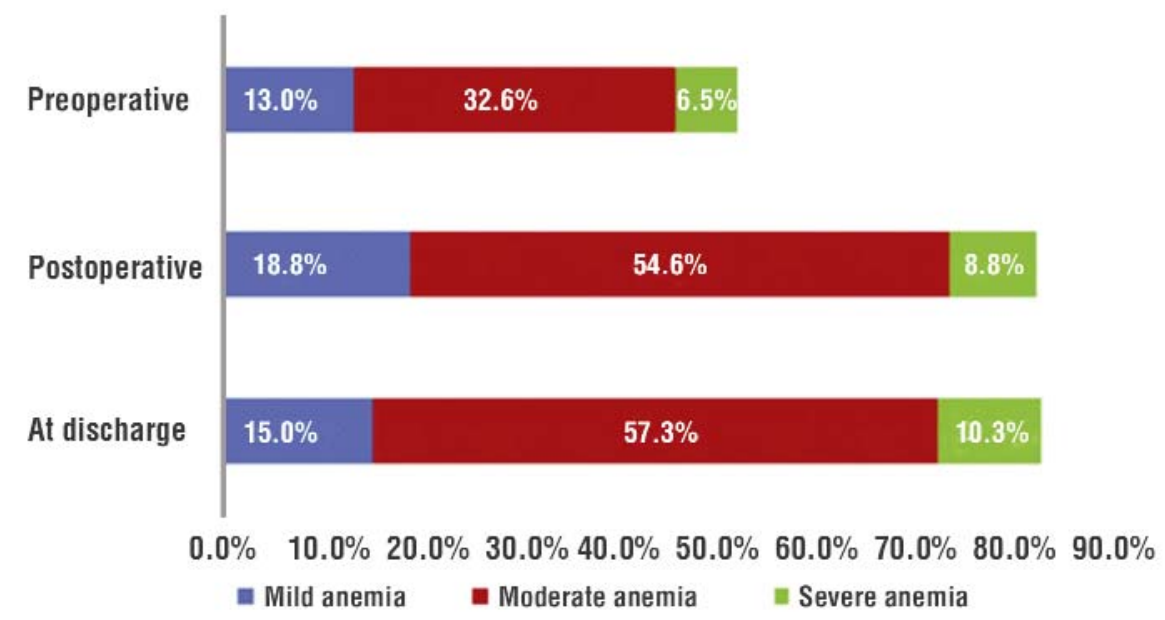

Characterization of the Non-anemic Versus Anemic Colorectal Cancer patients

The evaluation of different variables of nonanemic versus anemic colorectal patients is presented in Table 2. Anemia was more likely to occur in patients with advanced age (67.9 vs. 63.1 years, $p=0.005)$, low BMI (25.9 vs. $27.3 \mathrm{~kg} / \mathrm{m} 2, \mathrm{p}=0.026)$, and colon cancer (62.6 vs.37.4\%, p<0.001). Colorectal cancer patients with preoperative anemia had lower values of $\mathrm{Hb} 1$ (10.4 vs. $13.6 \mathrm{~g} / \mathrm{dL}, \mathrm{p}<0.001)$, $\mathrm{Hb} 2$ (9.6 vs. $11.7 \mathrm{~g} / \mathrm{dL}, \mathrm{p}<0.001)$ and $\mathrm{Hb} 3$ (9.5 vs. $11.4 \mathrm{~g} / \mathrm{dL}, \mathrm{p}<0.001)$. The transfusion rate was 8.6 times higher and the hospital LOS was prolonged (11.4 vs. 10.3 days, $\mathrm{p}=0.04$ ) comparing with non-anemic patients.

\section{Evaluation of the Tumor Location - Colon Versus Rectal Cancer}

A comparative analysis of data from colon and

Table 3. Perioperative variables of colon cancer versus rectum cancer patients

\begin{tabular}{|c|c|c|c|c|}
\hline & $\begin{array}{c}\text { All patients } \\
n=260\end{array}$ & $\begin{array}{c}\text { Colon cancer patients } \\
n=123\end{array}$ & $\begin{array}{l}\text { Rectum cancer patients } \\
\qquad n=137\end{array}$ & $p$ \\
\hline Age (yr) & $65.6(11.1)$ & $66.6(11.3)$ & $64.6(11)$ & 0.024 \\
\hline \multicolumn{5}{|l|}{ Gender, n (\%) } \\
\hline Male & $150(57.7)$ & $64(52)$ & $86(62.8)$ & 0.081 \\
\hline $\mathrm{BMI}\left(\mathrm{kg} / \mathrm{m}^{2}\right)$ & $26.6(5)$ & $26.8(4.5)$ & $26.4(5.4)$ & 0.727 \\
\hline Surgery duration (min) & $126(74.5)$ & $124.9(73.4)$ & $125.7(76.1)$ & 0.866 \\
\hline \multicolumn{5}{|l|}{ Blood loss, (ml) } \\
\hline Intraoperative & $200.4(202.7)$ & $159.4(145.8)$ & $236.9(237)$ & 0.051 \\
\hline Postoperative & $119.9(102.9)$ & $108.6(97.4)$ & $129.9(107)$ & 0.091 \\
\hline \multicolumn{5}{|l|}{ Hemoglobin $(\mathrm{g} / \mathrm{dl})$} \\
\hline $\mathrm{Hb} 1$ & $12(2.1)$ & $11.3(2.2)$ & $12.5(1.9)$ & 0.001 \\
\hline $\mathrm{Hb} 2$ & $10.6(1.6)$ & $10.3(1.6)$ & $10.8(1.6)$ & 0.003 \\
\hline $\mathrm{Hb} 3$ & $10.4(1.6)$ & $10.2(1.5)$ & $10.7(1.6)$ & 0.031 \\
\hline \multicolumn{5}{|l|}{ Anemia prevalence, $n(\%)$} \\
\hline Preoperative & 136 & 77 (62.6) & $59(43.1)$ & 0.001 \\
\hline Postoperative & 214 & $105(85.4)$ & $109(79.6)$ & 0.220 \\
\hline At discharge & 215 & $105(85.4)$ & $110(80.3)$ & 0.280 \\
\hline Transfusion rate, $\mathrm{n}(\%)$ & $62(23.8)$ & $34(27.6)$ & $28(20.4)$ & 0.173 \\
\hline ICU LOS (days) & $1.3(1.9)$ & $1.3(1.5)$ & $1.4(2.2)$ & 0.829 \\
\hline Hospital LOS (days) & $11(4)$ & $11(3.7)$ & $10.8(4.1)$ & 0.896 \\
\hline
\end{tabular}


Figure 3. Perioperative anemia prevalence and severity in rectal and colon cancer
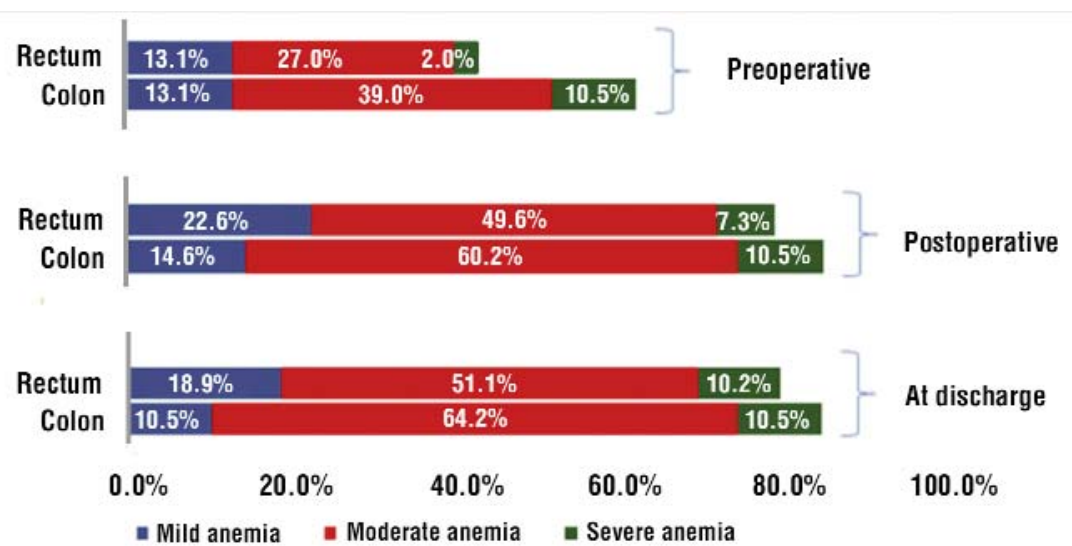

rectal cancer patients is presented in Table 3 and Fig. 3. Colon localization of the tumor was significantly associated with lower values of hemoglobin $\mathrm{Hb} 1$ (11.3 vs. $12.5 \mathrm{~g} / \mathrm{dL}, \mathrm{p}=0.001$ ), $\mathrm{Hb} 2$ (10.3 vs.10.8 g/dL, p=0.003), and $\mathrm{Hb} 3$ (10.2 vs. $10.7 \mathrm{~g} / \mathrm{dL}, \mathrm{p}=0.031)$. In the preoperative period, anemia was more prevalent (62.6 vs. $43.1 \%, \mathrm{p}=0.001)$, with higher values of severe anemia (10.5 vs. $2.9 \%, \mathrm{p}=0.001)$ in colon cancer patients, as shown in Fig. 3. The transfusion rate was also higher but nonsignificantly $(27.6$ vs. $20.4 \%, \quad p=0.173)$. Surgery duration, intra and postoperative bleeding and ICU and hospital LOS were comparable between the two tumor types.

\section{Discussion}

This retrospective cohort study shows a high prevalence of perioperative anemia in colorectal cancer patients.

In the preoperative period, more than half of the patients were anemic at hospital admission with two thirds presenting anemia of moderate and severe degree. Anemia prevalence in surgical oncological patients, irrespective of the tumor site, evaluated in our institution during the same time period, was $35.5 \%$, with the highest values of $47.7 \%$ in lower gastrointestinal surgery $(16,17)$. The percentage of patients with severe anemia (6.5\%) was higher than the transfusion rate $(2.3 \%)$, highlighting the existence of a low transfusion trigger on the preoperative period.
In addition to the high preoperative anemia prevalence, a progressive and significant decrease of the hemoglobin levels during hospitalisation was recorded. Accordingly, in the postoperative period, anemia prevalence markedly increases. These results implicate that anemic patients submitted to surgery aggravated the severity of anemia and $30 \%$ of normal hemoglobin patients developed anemia after the operation, despite a mean value of intraoperative blood loss less than $300 \mathrm{ml}$. The intra and postoperative transfusion rate was lower than other published data $(12,18)$, probably related to the low transfusion trigger. As we previously showed in a retrospective analysis, the transfusion trigger in surgical oncological patients in the postoperative period in our unit was $\mathrm{Hb}=8.2(0.9) \mathrm{g} / \mathrm{dL}$ (19).

The high prevalence of preoperative anemia together with the acceptance of lower transfusion thresholds and a short postoperative LOS resulted in more than $80 \%$ of colorectal patients being anemic at hospital discharge. This is an important problem due to 2 reasons. Firstly, because, in the absence of any treatment, anemia recovery at home can be very slow, in some patients taking more than one year. Secondly, because most of the colorectal cancer patients will need adjuvant therapy after surgery. In order to start chemotherapy, the current recommendations set a hemoglobin value superior to $9 \mathrm{~g} / \mathrm{dL}$ (20), so many patients will finally receive $\mathrm{RBC}$ transfusion.

The presence of preoperative anemia in 
colorectal cancer was associated with older age, and colon location of the tumor and significantly increased the transfusion rate, results consistent with other reported data in surgical patients irrespective of tumor type or location $(6,7,21,22)$.

Patients diagnosed with rectal cancer presented, at hospital admission, lower anemia prevalence versus colon cancer patients. During the postoperative period the number of anemic patients almost doubled because of the combined effects of intraoperative bleeding (nonsignificant higher values versus colon surgery) and a low transfusion trigger.

In order to reduce anemia and avoid transfusion, Patient Blood Management (PBM) programe was developped and is currently recommended by World Health Organisation as a multimodal and multidisciplinary intervention (23). The program objectives are to identify patients at risk of transfusion and to provide a managed plan aimed to preserve the own blood for reducing or eliminating the need of $\mathrm{RBC}$ transfusion (24). In Romania, the PBM Initiative Group recently published an implementation guide, approved and recommended by the Minister of Health (25). However, specific PBM strategies for oncological surgical patients are insufficiently defined. The high prevalence of anemia in all phases of the perioperative period urges the application of PBM in colorectal cancer patients.

\section{Conclusions}

Colorectal cancer patients have a high prevalence of perioperative anemia, exceeding $80 \%$ at hospital discharge and requiring transfusion in about $25 \%$ of cases. There is an urgent need of Patient Blood Management program implementation in this selected group of surgical patients in an effort to improve short and long-term outcome.

\section{Acknowledgments}

The database used in this study was created by the Patient Blood Management Romanian Group for the 2017 National Audit on the Prevalence of Anemia and Transfusion.

\section{References}

1. Global Cancer Observatory Globocan 2018. Cancer over time incidence and mortality. Cancer tomorrow. http://gco.iarc.fr

2. Siegel RL, Miller KD, Jemal A. Cancer statistics, 2018. CA Cancer J Clin. 2018;68(1):7-30.

3. Horowitz M, Neeman E, Sharon E, Ben-Eliyahu S. Exploiting the critical perioperative period to improve long-term cancer outcomes. S.Nat Rev Clin Oncol. 2015;12(4):213-26.

4. Kurosawa S. Anesthesia in patients with cancer disorders. Curr Opin Anaesthesiol 2012;25:376- 84.

5. Snyder GL, Greenberg S. Effect of anaesthetic technique and other perioperative factors on cancer recurrence. $\mathrm{Br} J$ Anaesth 2010; 105:106-15.

6. Musallam KM, Tamim HM, Richards T, Spahn DR, Rosendaal FR, Habbal A, et al. Preoperative anaemia and postoperative outcomes in non-cardiac surgery: a retrospective cohort study. Lancet. 2011:378(9800): 1396-407.

7. Leichtle SW, Mouawad NJ, Lampman R, Singal B, Cleary RK. Does preoperative anemia adversely affect colon and rectal surgery outcomes? J Am Coll Surg. 2011;212(2):187-94

8. De Hert S, Staender S, Fritsch G, Hinkelbein J, Afshari A, Bettelli G, et al. Pre-operative evaluation of adults undergoing elective noncardiac surgery. Updated guideline from the European Society of Anaesthesiology. Eur J Anaesthesiol. 2018;35(6):407-465.

9. Tavare AN, Perry NJ, Benzonana LL, Takata M, Ma D. Cancer recurrence after surgery: direct and indirect effects of anesthetic agents. Int J Cancer. 2012 Mar 15;130(6):1237-50. Epub 2011 Nov 9.

10. Spahn DR, Goodnough LT. Alternatives to blood transfusion. Lancet. 2013 May 25;381(9880):1855-65.

11. Al-Refaie WB, Parsons HM, Markin A, Abrams J, Habermann EB. Blood transfusion and cancer surgery outcomes: a continued reason for concern. Surgery. 2012;152(3):344-54.

12. Acheson AG, Brookes MJ, Spahn DR. Effects of allogeneic red blood cell transfusions on clinical outcomes in patients undergoing colorectal cancer surgery: a systematic review and meta-analysis. Ann Surg 2012; 256(2):235-44.

13. Wu HL, Tai YH, Lin SP, Chan MY, Chen HH, Chang KY. The impact of blood transfusion on recurrence and mortality following colorectal cancer resection. A propensity score analysis of 4030 patients. Sci Rep. 2018 Sep 6;8(1):13345.

14. Cata JP, Wang H, Gottumukkala V, Reuben J, Sessler DI. Inflammatory response, immunosuppression, and cancer recurrence after perioperative blood transfusions. $\mathrm{Br} \mathrm{J}$ Anaesth. 2013;110(5):690-701.

15. Goubran HA, Elemary M, Radosevich M, Seghatchian J, El-Ekiaby $\mathrm{M}$, Burnouf T. Impact of Transfusion on Cancer Growth and Outcome. Cancer Growth Metastasis. 2016:9:1-8.

16. Ristescu I, Patrascanu E, Popova 0, Faris M, Grigoras I. Perioperative hemoglobin dynamics in surgical cancer patients. Eur J Anaesthesiol, 2017; 34 (e-supp 55), A1-341.

17. Ristescu I, Jitca M, Filip D, Fecheta R, Rusu D, Patrascanu E, Grigoras I. Analysis of Perioperative Blood Transfusion in Oncologic Surgery with High Risk of Bleeding - a comparative study. Rom J Anaesth Int Care 2018; 25, suppl 1.

18. Calleja JL, Delgado S, del Val A, Hervás A, Larraona JL, Terán Á, et al. Ferric carboxymaltose reduces transfusions and hospital stay in patients with colon cancer and anemia. Int $\mathrm{J}$ Colorectal Dis. 2016;31(3):543-51.

19. Ristescu I, Patrascanu E, Popova 0, Stoica R, Gaidur M, Grigoras I. What is the haemoglobin transfusion trigger for postoperative oncological patients? Rom J Anaesth Int Care 2017; 24, suppl 1.

20. National Comprehensive Cancer Network - NCCN

21. Fowler AJ, Ahmad T, Phull M, Allard S, Gillies MA, Pearse RP et al. Meta-analysis of the association between preoperative anaemia and mortality after surgery. BJS 2015;102:1314-1324. 
22. Gombotz H, Rehak PH, Shander A, Hofmann A. Blood use in elective surgery: the Austrian benchmark study. Transfusion. 2007; 47(8):1468-80.

23. WHO Global Forum for Blood Safety: Patient blood management https://www.who.int/bloodsafety/events/gfbs_01_pbm/en

24. Society for the Advancement of Blood Management. https://www. sabm.org/education

25. Filipescu D, Banateanu R, Beuran M, Burcos T, Corneci D, Cristian D, et al. Perioperative Patient Blood Management Programme. Multidisciplinary recommendations from the Patient Blood Management Initiative Group. Rom J Anaesth Intensive Care. 2017; 24(2):139-157. 